tistical package; LEX, a word processing program; SPIDER, a library of image processing routines; NAG, a library of numerical algorithms). The next level is composed of what are termed 'GGU programs', programs originally written by GGU employees or obtained from elsewhere and installed at GGU. These programs are maintained by GGU's computing group, because they are useful to large groups in GGU. Examples are programs for geographical transformations, plotting of maps and geochemical analyses, norm calculations, etc. The third level consists of 'user programs', maintained by the users themselves for their own use. This level includes several programs running on external computers and many sequential file data bases on a personal/ departmental basis.

Many and varied jobs, including programs for most types of geoscience interpretation work, are run on GGU's VAX computer by nearly 60 regular users. Three programmers assist the users in different ways and a computer scientist will be added to the staff in the spring of 1988. Both development and production type processing take place.

\section{Trends for the near future}

Recently, GGU's needs and obligations for central data bases were analyzed by an internal working group which recommended the construction of central GGU data bases for scientific data. The development of the central data bases will take place in steps, starting with scientific information related to geological samples (sample information, sample description, results of analyses) and later moving on to other types of data, e.g. map-related data with areal extent, glaciological data, etc.

Another main trend which GGU has already embarked upon is the increased integration of map plotting facilities.

An increased integration of the processing of mineralogical/chemical analyses and interpretation, based on results from samples, is foreseen.

Image processing has been used by GGU in various areas. Suitable software will be installed, thus gradually updating GGU's capability for data synthesis, based on information from GGU's data bases and from other sources. In some cases closer ties will be established to GGU's map production facilities. To some extent this has already happened for data types which are well suited for computer handling, e.g. geophysical and geochemical data.

In general, GGU's strategy calls for increasing integration and rationalization of computer application, including transfer of GGU programs from external computer facilities to GGU's VAX-8200. Hardware build-up will take advantage of the network facilities provided by DEC A/S.

\title{
Geological reconnaissance in the Precambrian basement of the Atâ area, central West Greenland
}

\author{
C. Knudsen, P. W. U. Appel, B. Hageskov and L. Skjernaa
}

Geological reconnaissance was carried out in July 1987 as part of regional geological investigations planned for 1986-1992. The field work was carried out from three field camps with logistic support from GGU cutter 'J. F. Johnstrup', a helicopter and a rubber dinghy. The mapping was made on aerial photographs.

\section{General geology}

The area has been mapped on a reconnaissance scale (map sheet 1:500 000) and is described by Escher \& Burri (1967). Kalsbeek et al. (in press) made an isotopegeochemical study of some of the rocks in the area. Steenfelt (1987) carried out a regional stream-sediment geochemical programme, and the mining companies
Kryolitselskabet Øresund A/S and Vestgron Mines Ltd. have prospected in the area.

Escher \& Burri (1967) divided the rocks in the area into the infracrustal Jakobshavn gneiss and Atâ granite, and the Anap nunâ supracrustals (fig. 1). They described a gradual transition from the mainly granodioritic and locally migmatitic Jakobshavn gneiss to the very little deformed Atâ granite. Escher \& Pulvertaft (1976) described the rocks as belonging to the Proterozoic Rinkian mobile belt (a continuation of the Foxe fold belt in Baffin Island) because dome and basin type structures described by Escher \& Burri (1967) resemble those of the Rinkian. Escher \& Pulvertaft describe the area as separated from the Proterozoic Nagssugtoqidian mobile belt to the south by the Pâkitsoq shear zone. 


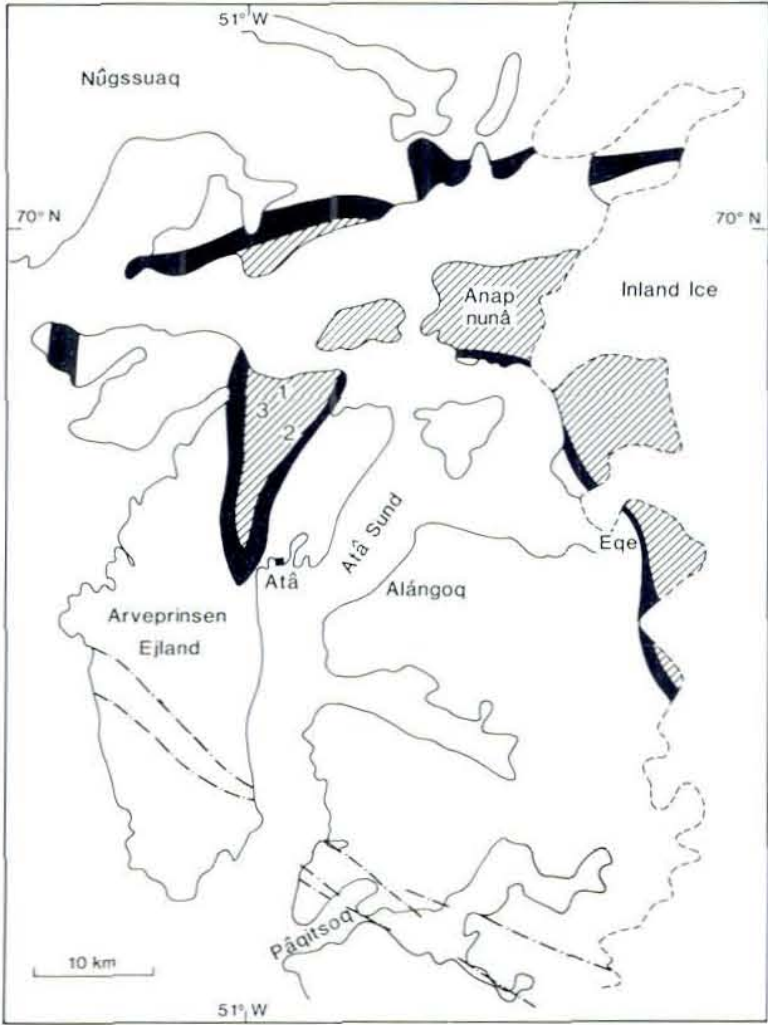

Supracrustral rocks in greenschist facies

Supracrustal rocks in amphibolite facies

Basement (mainly orthogneiss)

Fig. 1. Generalised geological map of the Atâ area (after Escher \& Burri, 1967).

The supracrustal rocks in the area consist of igneous and sedimentary rocks that have undergone greenschist to amphibolite facies metamorphism (fig. 1). A wide range of metamorphosed igneous rock types are represented, ranging from ultramafic rocks to intermediate and acid metavolcanics. The metasediments consist of a variety of siliciclastic rocks, as well as marble, chert and iron-formation. At least two generations of basic intrusive rocks are found in the supracrustals. Abundant massive and disseminated sulphide mineralisations have been found in the supracrustals.

The major part of the fieldwork was in the supracrustal rocks at Eqe and on Arveprinsen Ejland. Further the transition from low strain Atâ granitoids to gneiss and migmatite as well as the fault and shear zones at Pâqitsoq were also studied. However, as only three weeks were spent in the area the following must be regarded as a preliminary report.

\section{The supracrustals}

Eqe. Chlorite schist is the most abundant rock type in the supracrustal rocks of this area (figs 4 and 5); it consists mainly of chlorite and plagioclase with varying amounts of carbonate and calcsilicate minerals. Locally the chlorite schist contains carbonate lenses or schlieren, and the schists are cut by quartz and carbonate veins. In the eastern part of the area pillow structures (fig. 2) deformed to varying degrees can be observed, and locally it is possible to determine the stratigraphic way up from the shape of the pillows. Observations indicate that this is towards the west, which means that the supracrustal sequence is inverted. The presence of pillow structures shows that the chlorite schists have been formed at least partly by metamorphism of basic submarine lavas. Locally it is possible to identify relict rims on the pillows, and carbonate or calcsilicate in the space between pillows. These carbonate filled cavities may be a precursor to the carbonate schlieren seen in the chlorite schist.

The chlorite schist is intruded by (meta-)dolerite sills, locally with relic ophitic texture, but where heavily deformed these metadolerites are difficult to differentiate from the metavolcanic mafic schists, and they may be more abundant than indicated on the map (fig. 4). The metadolerites are cut by carbonate and quartz veins and are locally heavily altered.

As indicated in the tentative stratigraphy (fig. 5), metasedimentary horizons are fairly widespread in the supracrustal sequence. In the stratigraphically lower

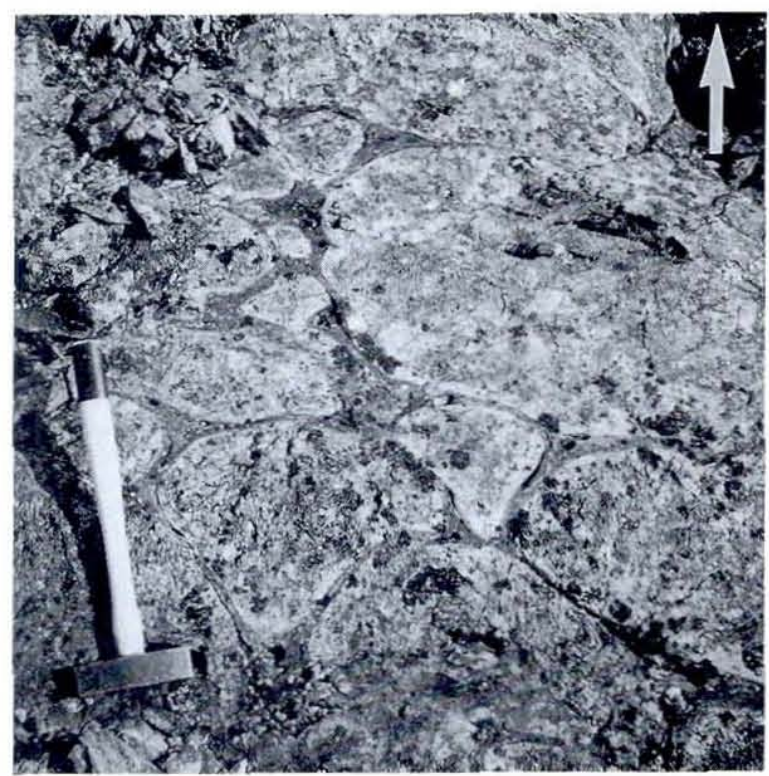

Fig. 2. Pillow lava. Stratigraphic way up is indicated by arrow. 
part there is a thick metasedimentary sequence dominated by quartzites and quartz-feldspar-sericite schists, locally fuchsite-rich or with intercalations of impure, dolomite-dominated carbonates. Several sulphide (mainly pyrite) bearing rust zones occur in these metasediments, often associated with the fuchsite. In the upper part of this sequence a deformed intraformational conglomerate is seen. In the upper part of the supracrustals the metasediments generally consist of intimately interlayered phyllites and quartz-feldspar-sericite schists, locally with graded bedding (fig. 3 ). These rocks are interpreted as metamorphosed flysch facies rocks. They are interlayered with 10 to $50 \mathrm{~m}$ thick sheets of chlorite schist. In the south-western part of the Eqe area, this part of the sequence is characterised by 1 to 5 $\mathrm{m}$ thick horizons of iron-formation interlayered with phyllites and quartz-sericite schists.

Marble occurs as horizons up to $30 \mathrm{~m}$ thick in the northern part of the area, at the same stratigraphic level as the iron-formation which is, however, not found in this part of the area. In the southern part of the supracrustals carbonate layers only up to $2 \mathrm{~m}$ thick are found. In addition to the marble horizons, carbonate is widespread in the supracrustal pile, occurring between pillows as discordant veins and as schlieren in the chlorite schists.

The upper part of the supracrustal sequence is dominated by a homogeneous, grey quartz-feldspar-sericite schist locally with coarse feldspar megacrysts, and interpreted as felsic metavolcanic rocks.

The supracrustals are cut by mafic dykes which are slightly folded.

The westernmost part of the supracrustal area at Eqe is dominated by amphibolites, cut by a light, granitic biotite orthogneiss. This gneiss is assumed to belong to the Atâ granitoids and forms semi-concordant sheets in the supracrustals. These orthogneiss sheets have participated in the isoclinal folding which can be observed in the amphibolite dominated supracrustal rocks. The first occurrence of orthogneiss in the supracrustals can be mapped (fig. 4), but there is a gradual transition from the first occurrence of orthogneiss in the supacrustals to where the orthogneiss constitutes more than $50 \%$ of the rock (an arbitrary boundary on fig. 4).

There is a general increase in deformational imprint from east to west, from the almost undeformed pillow lavas near the Inland Ice, through rocks with a well developed schistosity to the highly strained, foliated amphibolite facies rocks adjacent to the orthogneiss in the west. In the central part of the area, the schistosity is refolded in open kink folds often with carbonate veins in the axial plane. In the westernmost part a tightly to

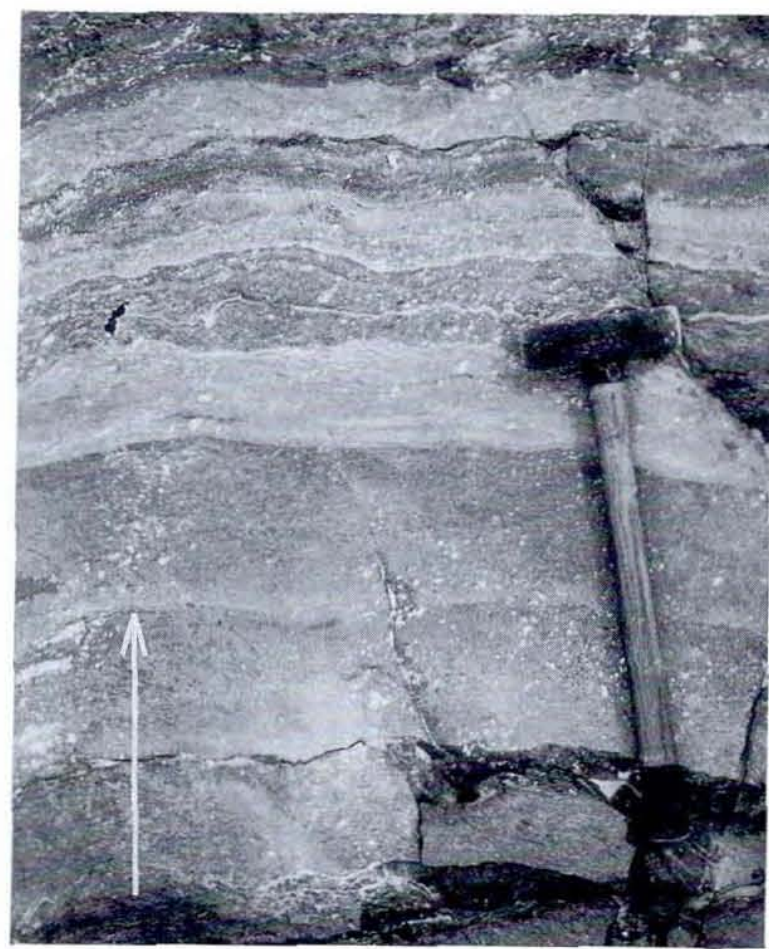

Fig. 3. Metasediments with graded bedding. Stratigraphic way up is indicated with arrow.

isoclinally folded foliation refolded by kink folds can be recognised.

East or north-east dipping 0.5 to $3 \mathrm{~m}$ wide breccia zones have been found, mainly in the metasediments west of the iron-formation, but breccia zones are also found in chlorite schists. These zones are sub-concordant, matrix- to clast-supported with phyllite and schist clasts and a carbonate, chlorite or quartz-rich matrix. The breccia contains sulphides (described below).

Arveprinsen Ejland. Chlorite schist is the dominant rock type in the supracrustal belt of this area. The chlorite schist can be divided into metamorphosed basic extrusive rocks and metadiorite/gabbro, and in the major part of the belt these are separate units. In highly strained areas it is however difficult to recognise the relic igneous texture/structure, and hence distinguish these as separate units. The metadiorite/gabbro is generally a medium- to coarse-grained, homogeneous rock consisting of chlorite and plagioclase, often with relic igneous texture. In the north-eastern part of the area, a very light coloured metadiorite/gabbro dominated by coarse plagioclase crystals is common and intrusive into the metasediments in the area. The metadiorite/gabbro is locally cut by carbonate veins, and in the north- 


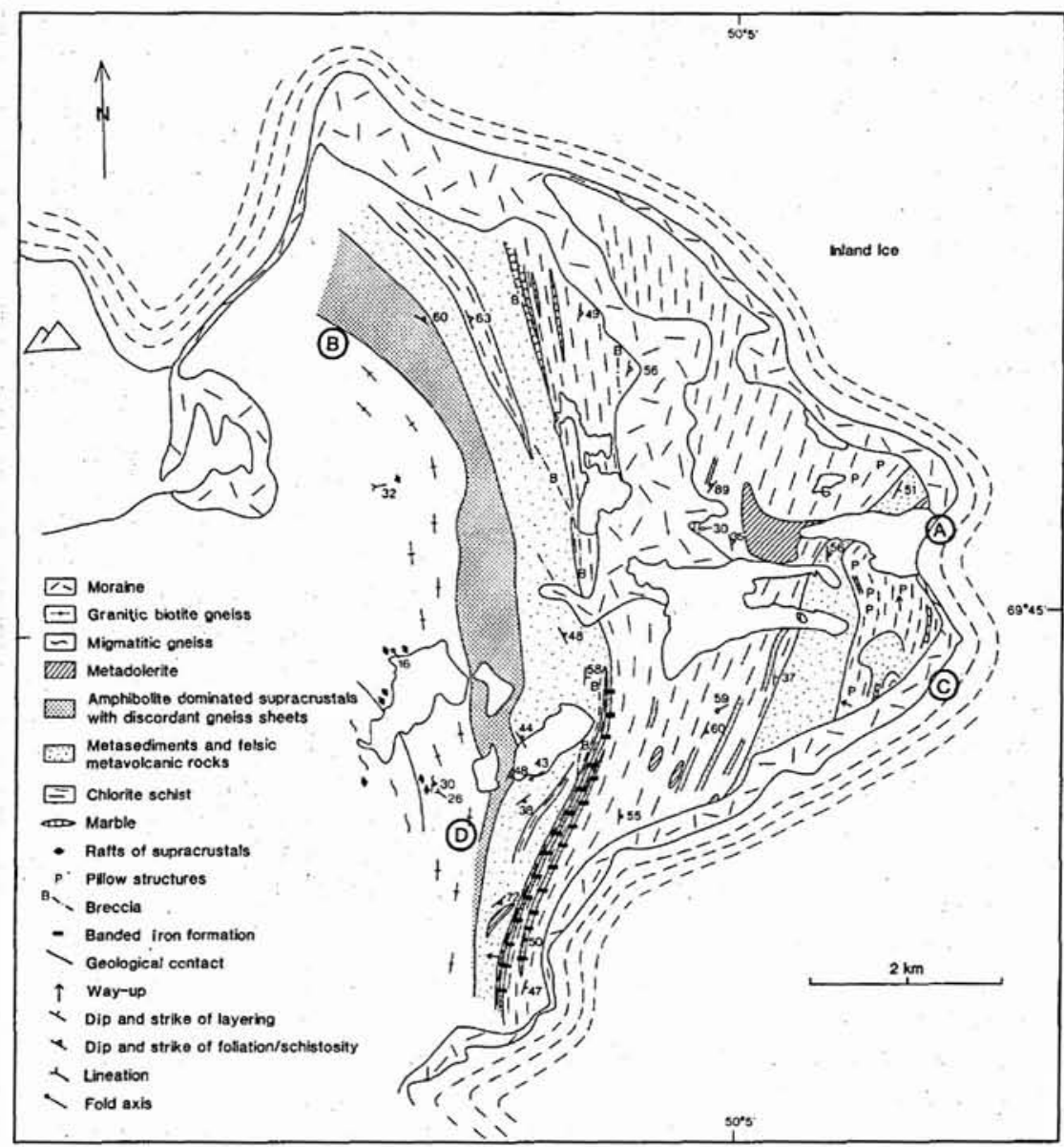

Fig. 4. Geological sketch map of the Eqe area.

western part of the supracrustals it is highly strained and contains carbonate schlieren.

The metasedimentary rocks are generally highly strained, without preserved sedimentary structures, and consist of quartz-feldspar-mica schist to quartzite locally with carbonate layers or carbonate veins. The quartzfeldspar-mica schist is often rusty due to disseminated pyrite or pyrrhotite, and locally small bodies of massive sulphides are found in the metasediments. In the northeastern part of the supracrustals, almost undeformed rafts of metasediments are found in the metagabbro. Sedimentary structures such as bedding, flame strucures and intraformational clasts/conglomerate can occasionally be observed. In the central and southern part of the supracrustals, felsic rocks containing feldspar phenocrysts are found. These rocks are likely to be metamorphic equivalents to acid and intermediate volcanics.

The metasediments and the metadiorite/gabbro are cut by slightly deformed and metamorphosed basic dykes.

The general trend in the supracrustal rocks at Ar- veprinsen Ejland is NNE-SSW with a steep to moderate dip towards the east or south-east. In the northern part of the island the trend is ENE-WSW, with overprinting by an east-west trending cleavage. The rocks have participated in large scale, recumbent folding around shallow, north-south trending axes. A crenulation lineation developed on an earlier schistosity is likely to be related to this event. Generally the strain as well as the metamorphic grade increases towards the contacts between the supracrustal rocks and the surrounding orthogneiss. The supracrustals contain a number of highly strained zones within the felsic metasedimentary rocks. In these highly strained zones, the metasediments are very fine grained and have a mylonitic appearance. In the western part of the supracrustals a metasediment horizon locally contains a carbonate rock, and this metasediment horizon also contains a carbonate breccia associated with highly strained rocks. The breccia is locally rich in sulphides (see below). All lithologies including the mylonites are cut by north-south and NNE-SSW trending faults. 
The age of the supracrustals. The Atâ granite and the Jakobshavn gneiss have been dated at approximately $2800 \mathrm{Ma}$, and siltstones from the Anap nunâ supracrustals have a minimum age of approximatly $1800 \mathrm{Ma}$, and are likly to be of Proterozoic age (Kalsbeek et al., in press). The Atâ granite is, however, intrusive into supracrustals on Arveprinsen Ejland and at Eqe, indicating that these are Archaean. In the Rinkian mobile belt, north of the Atâ area, large thrusts are responsible for interleaving of Archaean and Proterozoic rocks (Pulvertaft, 1986). This may also be the case in the Atâ area, although major thrust zones have not been identified in the supracrustals.

Metamorphism. The major part of the Eqe area is in greenschist facies, but in the western part the supracrustals have been metamorphosed under amphibolite facies conditions. The isograds are discordant to the layering and the amphibolite facies is transgressive in the south. The boundary between greenschist and amphibolite facies is also discordant to the layering in the supracrustals on Arveprinsen Ejland, and there is a general increase in metamorphic grade towards the contact to the orthogneiss. The rocks in the northern part of the area are mainly in greenschist facies whereas the supracrustals at Atâ are mainly in amphibolite facies (fig. 1). This means that carbonate rocks and the carbonate breccia (at 3 on fig. 1) disappear towards the south and are replaced by calcsilicate-rich rocks, common in the western part of the supracrustals near Atâ.

\section{The Atâ granitoids and the gneisses}

The relations between the Atâ granitoids and the gneisses and supracrustals of the area have been interpreted in different ways. Escher \& Burri (1967) thought that the granitoids (Atâ granite in their terminology) were formed by replacement mainly of the surrounding orthogneisses, but also of the supracrustals.

Kalsbeek et al. (in press) suggest that most of the gneisses in the area were formed by progressive deformation of the Atâ granitoids. This idea was supported by their isotopic studies. Age determinations give an age of about $2800 \mathrm{Ma}$ for the undeformed granitoids and about $2670 \mathrm{Ma}$ for the neighbouring gneisses, the latter age being considered to represent the time of deformation. Undeformed dykelets that cross-cut the granitoids yield the same age as the granitoids themselves.

The reconnaissance visit to the area in 1987 revealed that the boundary relations of the Atâ granitoid complex are more complex than formerly believed, and at least some of the relative chronology of the intrusive and deformational events in the area has now been established.

The Ata granitoids are mainly found in the northern half of Arveprinsen Ejland, at Alángoq and on Igdluluarssuit island south of Anap nunâ. The granitoids include a variety of types ranging from tonalites to granites, and where indications of the age succession are seen, the most granitic types are the youngest. The variation with respect to fabric is from isotropic, through homogeneously foliated and/or lineated to strongly folded. In narrow anastomosing zones, especially along the northeast and east coasts of Arveprinsen Ejland, the granitoids are strongly sheared and have been transposed to mylonites and phyllonites. The isotropic varieties of the granitoids are mainly found in the central parts of the complex, while the more deformed types are developed at the borders of the complex approaching the gneisses and towards the supracrustals. Locally there is a gradational contact between the granitoids and the surrounding gneiss. Intense shearing at the boundary between supracrustals and granitoids is seen.

Relations to the gneisses. A system of up to ten generations of cross-cutting dykelets is an important time marker. The composition of these dykelets ranges from tonalitic to granitic, the grain size ranges from fine grained to pegmatitic and widths from a couple of centimetres to a couple of metres. Although the dykelets obviously have different ages as they cross-cut each other, they seem to share a common place in the overall chronology. Several of the dykelets have characteristic appearances, which make them easily recogniseable from one locality to another, even when they are rather strongly deformed. For example, one generation of fine-grained tonalitic dykelets has rims of white pegmatite. Another generation of granitic to tonalitic dykelets show complex internal structures suggesting a synintrusion shearing parallel to the dykelets. Undeformed dykelets are found to cross-cut:

(1) Migmatitic grey gneisses. The folded migmatitic veins as well as the fabric in the gneiss are cut by the dykelets.

(2) Foliated and lineated Atâ granitoids.

(3) Isotropic Atâ granitoids.

Some parts of the Atâ granitoids either lack dykelets or contain only one or two generations. Either the dykelets intruded only parts of the pluton, or some parts of the pluton were emplaced after the intrusion of (most of) the dykelets. The dykelets have not been seen cutting the supracrustals. Deformed dykelets are found in 
Table 1. Relative chronology in the Atâ granitoids

$\begin{aligned} & \text { Deformation in parts of the area } \\ & \text { Dykelets (up to ten generations) } \\ & \text { Deformation in parts of the area } \\ & \text { Granite }\end{aligned}$
$\begin{aligned} & \text { Fine-grained tonalite } \\ & \text { Medium-grained tonalite }\end{aligned}$
$\begin{aligned} & \text { Deformation } \\ & \text { Veins }\end{aligned}$
$\begin{aligned} & \text { Grey plutonite (now migmatitic gneiss) } \\ & \text { Supracrustals }\end{aligned}$

foliated, lineated and folded gneisses along the middle of the west coast of Arveprinsen Ejland and at the west coast of Alangoq opposite Atâ. In both places there is a transition southwards from isotropic or slightly foliated host rock with undeformed dykelets to gneissic host rock with strongly deformed dykelets. These continue to banded gneisses where the dykelets have been transposed to gneissic bands, and only the most competent pegmatites can be recognised as strongly sheared veins or as rootless folds. These gneisses resemble some of the gneisses in the Pakitsôq area further south. At one locality, small folded pegmatite veins in metasediments are cut by tonalite belonging to the Atâ granitoids.
Summary of chronological relations. Based on the relations mentioned above an incomplete relative chronology is proposed (Table 1). The position of the migmatitic gneiss is somewhat uncertain; it may be considered to belong to an early phase of the Atâ granitoids separated from the others by a deformation. At Eqe a similar migmatitic gneiss contains xenoliths of amphibolite facies supracrustals, but the possibility that parts of the migmatitic gneiss have formed the basement to the supracrustals cannot be excluded. The relative age of possible Proterozoic supracrustals is not indicated in Table 1.

Table 2. Chemical analysis of sulphide-bearing grab samples

\begin{tabular}{lrrrrrrrrrr}
\hline $\begin{array}{l}\text { Sample } \\
\text { number }\end{array}$ & $\begin{array}{r}\mathrm{Au} * \\
(\mathrm{ppm})\end{array}$ & $\begin{array}{r}\mathrm{Ag} * \\
(\mathrm{ppm})\end{array}$ & $\begin{array}{r}\mathrm{Cu} \dagger \\
(\mathrm{pct})\end{array}$ & $\begin{array}{r}\mathrm{Zn} * \\
(\mathrm{ppm})\end{array}$ & $\begin{array}{r}\mathrm{Pb} \dagger \\
(\mathrm{ppm})\end{array}$ & $\begin{array}{r}\mathrm{As} * \\
(\mathrm{ppm})\end{array}$ & $\begin{array}{r}\mathrm{Sb} * \\
(\mathrm{ppm})\end{array}$ & $\begin{array}{r}\mathrm{W} * \\
(\mathrm{ppm})\end{array}$ & $\begin{array}{r}\mathrm{Fe} * \\
(\mathrm{pct})\end{array}$ & $\begin{array}{r}\mathrm{Co} * \\
(\mathrm{ppm})\end{array}$ \\
\hline 341442 & 0.10 & $<5$ & 0.03 & $<200$ & $<6$ & 4170 & 2 & $<8$ & 14.0 & 1050 \\
341445 & 3.44 & 23 & 1.20 & 300 & $<6$ & 359 & 1 & 70 & 6.3 & 73 \\
341448 & 0.81 & 30 & 1.52 & $<200$ & $<6$ & 151 & 1 & 20 & 9.3 & 50 \\
341453 & 0.05 & 5 & 0.15 & $<200$ & $<6$ & 24 & 0 & 120 & 2.3 & 26 \\
341489 & 12.30 & 44 & 2.67 & 630 & 70 & 67 & 4 & 17 & 8.7 & 72 \\
341510 & 0.62 & 320 & 13.10 & 9900 & 12200 & 3060 & 61 & $<11$ & 48.0 & 2890 \\
341511 & 0.08 & 44 & 1.17 & 55900 & 3930 & 7 & 3 & 27 & 54.9 & 930 \\
341528 & 0.12 & 59 & 0.30 & 22700 & 134 & 291 & 3 & 25 & 39.0 & 210 \\
\hline
\end{tabular}

Samples from Eqe

341442 Ankerite breccia (matrix supported).

341445 Silicified breccia (with chalcopyrite veins, matrix supported).

$341448 \quad-$ Brecciated phyllite (clast supported)

341489 - - (clast supported with carbonate and chalcopyrite veins).

Samples from Arveprinsen Ejland

$341510 \quad$ Massive sulphides (pyrite and chalcopyrite with subordinate pyrrhotite, sphalerite and galena).

341511 Massive sulphides (pyrrhotite and sphalerite together with amphibole).

341528 Massive sulphides (layered pyrite and sphalerite together with quartz).

* Neutron activation analysis (Bondar-Clegg, Canada).

$\dagger$ Atomic absorption analysis (average of two analyses). 


\section{Shear and fault zones at Pâkitsoq}

The Pâkitsoq area south of the Atâ granite complex is of considerable interest as Escher \& Burri (1967) suggested that the ESE-WNW trending fault zone seen in Pâkitsoq separates the Egedesminde complex in the south from a northern complex including the Umanak area. This fault zone is postulated to be the continuation of a Canadian fault zone along which a sinistral displacement of several hundred kilometres is suggested (Hoffman, in press). The Pâkitsoq area is a rather monotonous terrain formed by grey biotite orthogneisses of granodioritic to tonalitic composition. Presumably this orthogneiss mass includes elements of the Atâ granite complex. In the southern part of the area an augen gneiss occurs with scattered alkali feldspar megacrysts, up to $5 \mathrm{~cm}$ in size. In the country gneisses a little hornblende and garnet may be found. The gneisses have been exposed to migmatisation to varying degrees. The migmatites are cut by deformed irregular pink pegmatites likely to be of the same age as the dykelets in the Atâ granitoids. Subordinate amounts of basic rocks occur in agmatite and amphibolite horizons and in younger sheets of metadolerite.

Three major deformational events are recognised in the the Pakitsoq area:

The oldest. This took place under amphibolite facies conditions and resulted in folding of the migmatite structure and a pre-existing foliation.

Intermediate. This event was a ductile shearing under amphibolite facies conditions. The overall ESE-WNW trending structural grain of the Pâkitsoq area results from this event, and all over the area there is evidence of shearing followed by refolding of older structures. During this event an ESE-trending and moderately plunging stretching lineation was formed and most fold axes are parallel to this direction. The most intense shearing is seen in the interior part of Pâkitsoq, where heavily sheared gneisses, protomylonites and mylonites are possibly related to a north-east dipping thrust complex, with an oblique thrusting from E to ESE. In the mylonites intrafolial older folds refolded by younger folds are seen. The ductile shearing event took place after the intrusion of the metadolerite sheets, which are deformed to subconformable bodies in the gneisses. The metadolerites show boudinage, they have been intensly sheared along their margins, and minor shear zones may be seen in their otherwise well preserved central parts. This event of ductile shear took place presumably at the same time as the youngest deformation seen in the Atâ granitoids.
The most recent. This deformational event resulted in brittle faulting. The faults are subvertical, trend ESEWNW, and are associated with about $50 \mathrm{~m}$ wide zones of cataclastites. The amount of displacement has not been determined but the faults did not introduce any exotic rocks into the area and there are no metamorphic contrasts resulting from the faulting. The faults may be of importance, but at the moment there is no reason to suggest very large scale movements connected to the faulting.

\section{Mineral occurrences in the Atâ area}

An iron-formation and three types of sulphide occurrences have been found in the Atâ area. Grab-samples have been analysed by neutron activation and atomic absorption, and the results are listed in Table 2 .

Iron-formation. This has been studied in the central and southern part of the Eqe area, where it occurs in three horizons at the lowermost part of a metasedimentary sequence (fig. 5). The character of the iron-formation changes along strike, from a schistose magnetite rich rock interlayered with phyllites and quartz-sericite schist in the central part (in greenschist facies) to an isoclinally folded, banded garnet-quartz-magnetite rock in the southern part (in amphibolite facies). The ironformation is up to $5 \mathrm{~m}$ thick and can be followed $4 \mathrm{~km}$ along strike.

Disseminated sulphides. Supracrustals in all parts of the region contain rust zones caused by disseminated sulphides. These zones are up to $100 \mathrm{~m}$ long and a few metres wide, and the sulphide found is mainly pyrite, constituting up to 10 modal \% of the following rock types: quartzite locally with fuchsite, quartz-sericite schist, limestone/marble and carbonate rich-graphitic schists, chlorite schist, pillow lava and altered metadolerite.

Massive sulphides. These occur as bodies up to $20 \mathrm{~m}$ long and several metres wide associated with felsic supracrustals on Arveprinsen Ejland. The largest occurrence is the 'Anderson showing' (location 1 on fig. 1) which is an approximately $20 \mathrm{~m}$ long and $10 \mathrm{~m}$ thick lens of massive sulphides occurring together with finegrained, quartz-rich metasedimentary rocks. Two mineral assemblages are present here, a massive pyritechalcopyrite ore with subordinate galena (GGU 341510) and a pyrrhotite-chalcopyrite-sphalerite ore rich in amphibole (GGU 341511). Apart from this, a small lens of massive pyrite with subordinate quartz, 


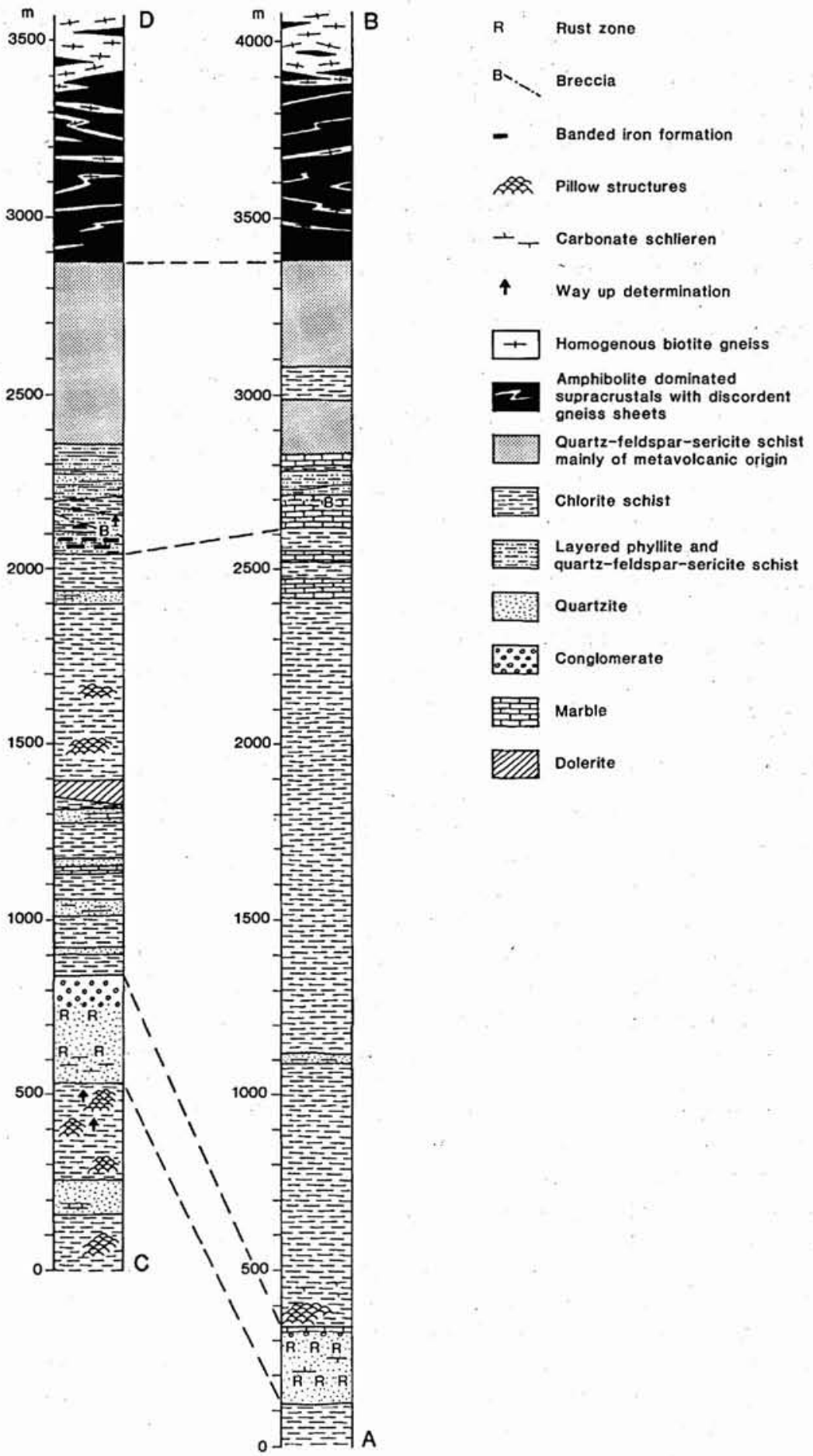

Fig. 5. Tentative columnar sections in the supracrustals at Eqe. Locations of the sections A-B and $\mathrm{C}-\mathrm{D}$ are indicated on fig. 4. The base of the supracrustal sequence has not been found.

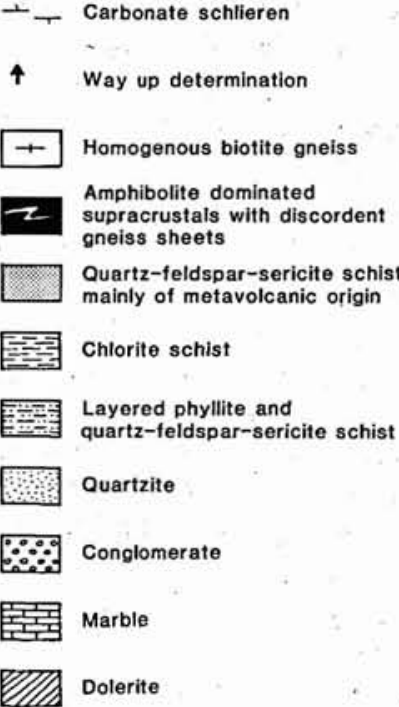

sphalerite rich layers and minor chalcopyrite (GGU 341528 ) is found at location 2 on fig. 1 . This lens is approximately $3 \mathrm{~m}$ long and $30 \mathrm{~cm}$ wide.
Sulphide impregnations in breccia. Disseminated sulphides are found in breccia zones in the supracrustals. The most interesting of these have been found at Eqe and on Arveprinsen Ejland. The breccia zones are semiconcordant and mainly found in quartz-sericite schist 
and phyllite, but are also found in chlorite schists and ultramafic rocks (on Anap nunâ). They generally have carbonate (ankerite and calcite), chlorite and quartz in the matrix. The breccia is often slightly porous. The sulphides, generally located in the matrix, consist dominantly of large, anhedral chalcopyrite with minor amounts of euhedral pyrite.

In the Eqe area several chalcopyrite-pyrite bearing breccia zones have been found (fig. 5), and in the southern part of the area a breccia up to $5 \mathrm{~m}$ wide could be followed $100 \mathrm{~m}$ along strike. The samples GGU 341442 , $341445,341448,341453$ and 341489 (Table 2) were collected in this zone. This breccia is located where Steenfelt (1987) found elevated gold values (up to $43 \mathrm{ppb}$ ) in stream sediments.

In the supracrustals at Arveprinsen Ejland a 1 to $5 \mathrm{~m}$ wide breccia zone has been followed for about $5 \mathrm{~km}$. The breccia ( 3 on fig. 1 ) is locally rich in sulphides, mainly pyrite, but locally massive chalcopyrite and sphalerite occur.

Acknowledgements. The field work was partly financed by grants from the Danish Natural Science Research Council (j.nr. 81-5656 (B. H.) and j.nr. 81-5650 (L. S.)). B. Damgaard carried out the atomic absorption determinations.

\section{References}

Escher, A. \& Burri, M. 1967: Stratigraphy and structural development of the Precambrian rocks in the area north-east of Disko Bugt, West Greenland. Rapp. Grønlands geol. Unders. 13, 28 pp.

Escher, A. \& Pulvertaft. T. C. R. 1976: Rinkian mobile belt of West Greenland. In Escher, A. \& Watt, W. S. (edit.) Geology of Greenland, 104-119. Copenhagen: Geol. Surv. Greenland.

Hoffmann, P. F in press: United plates of America, the birth of a craton: Annl Rev. Earth Planet. Sci. 16.

Kalsbeek, F., Taylor, P. N. \& Pidgeon, R. T. in press: Unreworked Archaean basement and Proterozoic supracrustal rocks from northeastern Disko Bugt, West Greenland: implications for the nature of Proterozoic mobile belts in Greenland. Can. J. Earth. Sci.

Pulvertaft, T. C. R. 1986: The development of thin thrust sheets and basement - cover sandwiches in the southern part of the Rinkian belt, Umanak district, West Greenland. Rapp. Grønlands geol. Unders. 128, 75-87.

Steenfelt, A. 1987: Gold in the fine fraction of stream sediments from supracrustal sequences in West Greenland. Unpubl. intern. GGU rep., 10 pp.

B. H. \& L. S., Institut for Almen Geologi, $\emptyset$ ster Voldgade 10, $D K-1350$ Copenhagen $K$, Denmark.

\title{
Progress in geochemical mapping of West Greenland
}

\author{
Agnete Steenfelt
}

Geochemical mapping based on low density sampling and analysis of stream sediment and stream water is part of the mineral resources evaluation programme undertaken by the Geological Survey of Greenland (Steenfelt $1987 \mathrm{a}, \mathrm{b})$.

In the field season of 1986 two areas were sampled, the inner Disko Bugt region (1:250 000 map sheet 69 V.2 and part of $70 \mathrm{~V} .2$ ), and the Godthåb region (map sheets 64 V.1 and 64 V.2).

\section{Sampling and analysis}

The sampling was carried out by one field team supported by a Bell 206 helicopter from Greenlandair Charter. At each sample station $200-300 \mathrm{~g}$ of stream sediment was collected from four to five sites in the stream bed; a $100 \mathrm{ml}$ stream water sample was taken; and the gamma radiation was measured by averaging five to ten scintillometer readings in the immediate surroundings of the sample site. The sample density is one sample per $20-30 \mathrm{~km}^{2}$.

The 608 stream-sediment samples were dry-sieved in the laboratory and the $<0.1 \mathrm{~mm}$ fraction was analysed by X-ray fluorescence at the Geological Survey of Greenland. A selection of 96 samples were also analysed by Instrumental Neutron Activation at BondarClegg, Canada. The conductivity and the fluoride concentration of the stream water samples were measured in a field laboratory. Table 1 lists the elements and basic statistical parameters for the concentrations determined by X-ray fluorescence and for the water analyses.

The X-ray fluorescence analyses for major and trace elements were made on a Philips PW 1606 multi-channel spectrometer. The analyses were made on glass discs and major elements were determined following the principles of Petersen \& Sørensen (1980) while the pro- 